\title{
Using Six Hats' Strategy In Enhancing Supervisory Skills OfEfl Counsellors And Their Intellectual Flexibility
}

\section{Ph.D, Heba M.Mohamed}

Associate professor at the Faculty of Education Curriculum \& Instruction Dept. Beni Suef University

\section{Abstract}

The main aim of the current study was to investigate
the effect of the six hats' strategy on enhancing
supervisory skills of English counsellors and their intellectual flexibility. The study was conducted in Beni Suef educational district. Twenty five EFL supervisors acting on as one study group were trained on supervisory skills using six hats' strategy .Statistical analysis of the data revealed that there were statistically significant differences between the mean scores of the experimental group students in the pre and post administration in the supervisory skills' situational test as well as in the intellectual flexibility' scale in favor of the post administration. The magnitude effect was big; thereby proving the effect of the six hats' strategy.

Keywords: Six Hats' Strategy, Supervisory skills, intellectual flexibility

\section{Introduction}

As a result of the current trends of recurrent developments overwhelming the globe, the world has come to such a stage of marvelous scientific progress and such a gigantic knowledge revolution that resulted in such radical changes in all life fields; social, economic, political and cultural. So man should meet all those changes in every field in an attempt to adapt with them. But man can never adapt with such changes unless s/he is able to take grip of the basics of his/her life, scientifically and pragmatically. So, education has to bear the responsibility in developing the human mind in order to be able to adapt with the use of available data, and to invest it in order to accommodate with such rapid changes impacting the world. This makes it necessary for education at large to adopt change all through educational stages as well as in the supervisory skills that counselors use while supervising teachers in classrooms. Change 
should also be adopted as per teaching methods, activities and strategies used in classrooms in addition to the ways followed in supervising teachers themselves. Since supervision is important for teachers as it guides them to be in the right track all time. It also can be a monitor for teachers towards development to cope up with the progress in all life fields. It should be well known that keeping supervision away from modern changes is never acceptable since this case will never create a modern counselor who is well qualified to deal with such an age with all of its tremendous changes.

The duties of the educational supervisor have been changed in a way that cover raising the efficiency of the instructor, improvement of curricula methods, aids, educational programs and developing the educational environment, through truthful teamwork among the instructor, the principal/ headmaster and the educational supervisor and integration of their roles and reinforcing the horizontal relationship among them (Aatwi, 2001).

In traditional adversial thinking, both parties are in conflict. Each party attempts to criticize the other points of view. The six hats strategy permits parallel thinking. Both sides wear each hat together as they explore all sides of an issue. The contradictory confrontation is replaced by a cooperative exploration of the subject.( De Bono, 1998).

For the improvement of the professional effect of the teaching staff, directors must behave to be perfect in the following areas: evaluation, observing and analyzing classroom observation information and other data, and translating the results of observations and the summary of data into meaningful conference feedback that guides and motivates teachers to enhance the instructional process .As supervision is based on discussion between the teachers and supervisors, there should be a new kind of discussion that is away from the traditional thinking that clarifies conflict. So, the six thinking hats' strategy appears as a creative strategy. While thinking in the normal way, one attempts to do too much at once. One may be looking at the 
information, forming ideas, and judging someone else's ideas all at the same time. The six hats' strategy allows persons to split thinking instead of attempting to do everything at once. It permits us to divide the different aspects of thinking. (De Bono, 1998).

In order to achieve the main objectives towards six thinking hats' strategy which aims at creative thinking, intellectual flexibility should be required for both of the users of this creative strategy. Intellectual Flexibility is necessary when unpredictability is a style of life, and learning quickly is the difference between success and failure. The capacity to get new knowledge quickly, to adjust one's perspective, adopt one's approach, leave behind outdated practices, and explore new possibilities for addressing new problems brings Leaders, member-leaders, and entire organizations a decided competitive advantage. The only way to prepare for the unexpected is to cultivate a humble and teachable attitude that fuels continuous learning.( McCloskey, 2014).

\section{Context of the problem}

Although there are many trends in the area of supervision and there are relationships between teachers and supervisors. The latter still use traditional ways concentrating on teachers' mistakes rather than advising them and helping them to improve. That's why the current study attempts to investigate how six hats strategy enhances supervisory skills and intellectual flexibility of EFL counsellors.

\section{Questions of the study}

The current study attempts to find answers to the following questions:

1. What is the effect of a training program based on six hats strategy on developing the supervisory skills of English counselors?

2. What is the effect of a training program based on six hats strategy on developing intellectual flexibility of English counselors? 


\section{Hypotheses of the study}

1. There is a statistically significant difference at 0.01 between the mean scores of the study group in pre and post administrations of the situational test in favor of the post administration.

2. There is a statistically significant difference at 0.01 between the mean scores of the study group in pre and post administrations of the intellectual flexibility' scale.

\section{Delimitations of the study}

\section{The current study is delimited to:}

1. Twenty five EFL counsellors at Beni Suef educational district.

2. Some supervisory skills including guiding the workorganizing the work-developing staff-managing performance- managing relations.

3. The second semester of the academic year 2015-2016.

\section{Terminology of the study}

The study acts as per the operational definitions of the following terms:

\section{Supervisory skills}

This term was used in the current study to refer to the necessary skills that help him/she achieves supervisory duties successfully representing in the following: Guiding the workorganizing the work-developing staff-managing performancemanaging relations.

\section{Six thinking hats' strategy}

This term was used in the current study to refer to the thinking strategy used to develop the English counselors' supervisory skills. They are six in colors: white, red, yellow, green, blue and black. Each color represents a way of thinking that differs from the other.

\section{Intellectual flexibility}

This term was used in the current study to refer to the ability to think reasonably, carefully, and creatively about a wide variety of topics, and decide well in different situations.It is the 
capability to think about new things, to think about old things in new ways, to adapt with unfamiliar ideas and situations, and to use insights and ideas from one field to problems in another.

\section{Significance of the study}

The significance of study conceals in discussing the educational supervision practices amongst educational supervisors as well as shedding the light on the six hats' strategy as a new supervisory practice. It is hoped that this study fulfills the following :

- Providing a clear vision for the responsible people, especially the Directorate of Educational Supervision and Training in the Ministry of Education, of Egypt, that may be implemented and get benefit of it in the field of educational supervision.

- Benefiting the personnel working in the field of educational supervision at directorates of education, through providing them with feedback about their practicing the characteristics of modern educational supervision.

- Enriching the educational supervision field in the related side with the characteristics of modern educational supervision.

- Recognizing their trends towards education profession that reinforces the educational process and developing the performance of teachers.

\section{Aims of the study}

This study aims at investigating the effect of using six thinking hats' strategy on the development of supervisory skills of the English counsellors as well as their intellectual flexibility.

\section{Instruments}

In conducting the current study, the following instruments were prepared and used by the researcher:

1. An achievement test.

2. An intellectual flexibility scale 


\section{Description of the achievement test}

The test contains fifteen multiple choice questions .The first three questions test the skill of guiding the work. The next four questions test the skill of organizing work. Three questions measure the skill of developing the staff. Two questions were used to measure the skill of managing performance. The last three questions test the skill of managing relations.

\section{Validity of the test}

To attain the validity of the achievement test, it was submitted to a jury of five specialists to judge it regarding the content of the test, number of questions, and the suitability of the test for the sample of the study.

To validate the achievement test, the correlation coefficient between the score of each part and the total scores of the test was calculated and the following table shows the results:

Table (1)The correlation coefficient with the total score of the prepost achievement test

\begin{tabular}{|l|c|}
\hline \multicolumn{1}{|c|}{ Test parts } & $\begin{array}{c}\text { Correlation coefficient with the } \\
\text { total score }\end{array}$ \\
\hline Guiding the work & $0.71^{* *}$ \\
\hline Organizing the work & $0.77^{* *}$ \\
\hline Developing staff & $0.69^{* *}$ \\
\hline Managing performance & $0.70^{* *}$ \\
\hline Managing relations & $0.73^{* *}$ \\
\hline
\end{tabular}

**Significant at 0.01

As shown in the previous table, the values of the correlation coefficient with the total score of the achievement test are high and significant at 0.01 .

\section{Reliability of the test}

Moreover, the researcher used Alpha technique to measure the reliability of the test. It was 0.88 . It is a suitable reliable coefficient for the test. The correlation coefficient between the marks of each question and the total marks of the achievement test ranges from 0.0 .80 to 0.84 . Those values are high and significant at 0.01 . 
Table (2)The Reliability of the achievement test with alpha technique

\begin{tabular}{|l|c|}
\hline Test parts & Reliability \\
\hline Guiding the work & $\mathbf{0 . 8 0}$ \\
\hline Organizing the work & $\mathbf{0 . 8 4}$ \\
\hline Developing staff & $\mathbf{0 . 8 1}$ \\
\hline Managing performance & $\mathbf{0 . 8 0}$ \\
\hline Managing relations & $\mathbf{0 . 8 2}$ \\
\hline
\end{tabular}

\section{(2) Intellectual flexibility scale Description}

The scale has been divided into three parts: the first part is entitled" Considering new information and perspectives". It has four items. The second part is: integrating information that contains seven items. The last part is entitled: clarifying complexity. It has seven items.

\section{Validity}

To attain the validity of the intellectual flexibility scale, it was submitted to a jury of five specialists to judge it .To also validate the scale, the correlation coefficient between the score of each part and the total scores of the scale was calculated. The scale has been divided into three parts: the first part is entitled" Considering new information and perspectives". It has four items. The alpha score has been calculated and was 0.81 which is a high score. The correlation with the total score was also calculated and was 0.69 which was also a high score. The second part is: integrating information that contains seven items. The alpha score was also calculated. It was 0.86 which is a high score. The correlation with total score for the second part was also calculated which was 0.73 which is a high score and significant at 0.01 . The last part is entitled: clarifying complexity. It has seven items. The alpha score was also calculated for this part. I t was 0.86 which was high in addition to the high score of the correlation of this part with the total score which is 0.73 and significant at 0.01 .

\section{Reliability}

As for the intellectual flexibility scale, its reliability has been calculated by alpha technique as shown in the following table: 
Table (3) The reliability of the intellectual flexibility scale

\begin{tabular}{|l|c|c|c|}
\hline \multicolumn{1}{|c|}{ Items } & $\begin{array}{c}\text { Number of } \\
\text { items }\end{array}$ & Alpha & $\begin{array}{c}\text { Correlation with } \\
\text { total score }\end{array}$ \\
\hline $\begin{array}{l}\text { Considering new } \\
\text { information andperspectives }\end{array}$ & 4 & 0.81 & $0.69^{* *}$ \\
\hline Integrating information & 7 & 0.86 & $0.73^{* *}$ \\
\hline Clarifying complexity & 7 & 0.86 & $0.73^{* *}$ \\
\hline
\end{tabular}

**Significance at 0.01

\section{Procedures}

In conducting the current study, the following procedures were followed

1. One study group ( $\mathrm{N}=25$ Counsellors) in Beni Suef directorate participated.

2. They administered the achievement test as a pre-test in one class session. This was at the beginning of the second semester, academic year 2015-2016.

3. Also, they administered the intellectual flexibility scale in one class session. This was at the beginning of the second semester, academic year 2015-2016.

4. Then, they were trained on supervisory skills using "six thinking hats' strategy .

5. By the conclusion of the intervention, the participants were post tested using both instruments.

\section{Review of literature}

This section is divided into three main parts: concept of supervisory skills, rationale of six hats strategy, intellectual flexibility.

\section{Concept of supervisory skills}

Supervision is a means of advising, guarding, refreshing, encouraging, stimulating, improving and overseeing their cooperation in order for the supervisor to be successful in their tasks or supervision. Ogunu (1998:128) defines supervision as the art of managing the activities of teachers and others working in the school to be sure that they conform with generally accepted principles and practice of education and the restricted 
policies and guidelines of education authority which controls the system of education and providing professional guidance to them (school personnel) to enhance the conditions which affect the learning and growth of students and teachers .

Igwe (2001) stated that to supervise means to direct, oversee, guide or to make sure that expected standards are met. Thus, supervision in the school means that the developed rules, regulations, principles are followed to maintain the minimum standard lay for the schools are carried out effectively and efficiently. Supervisory skills have been defined as supervisor's daily work life: Guiding the Work, Organizing the Work, Developing Staff, Managing Performance, and Managing Relations (Soltani, 2004; Bernard \& Goodyear, 2004)

\section{Basic Principles for Effective Supervision}

According to ( Obiweluozor; Momoh;Ogbonnaya ,2013) , there are some principles for effective supervision as follows:

1. There should be a good rapport away from pressure and stress.

2. Staff must be oriented about the quality of work expected from them. Also new staff must be given orientation concerning the job.

3. There should be a room for beneficial criticism, that is poor work should be criticized, advice should be given to the affected party.

4. School staff should be given a chance to prove their capability, they should be allowed to use their initiative when doing certain task or taking decision in some important areas.

5. School staff should be stirred and encouraged to work, to increase their productivity that enhances administrative goals .

\section{Features of school supervision includes}

Ojelabi, 1981 pointed out that there are some features of school supervision that include: 
1. It sheds a light on the improvement of teaching and learning.

2. It is mostly based on human relation principles rather than the traditional view that sees supervisors as masters and teachers are mere servants.

3. It usually includes a lot of discussion and exchange of ideas to discover which method works well.

4. It lasts few days rather than few hours.

5. They usually come as a colleague rather than fault-finder

6. It is regular, scheduled and well planned.

7. It helps in enhancing the morale of teacher and pupils in doing what they do well and in correcting what they do not do well.

Supervision is a task that requires careful, firm and objective assessment. Therefore those given the responsibility should be very careful in carrying out their duties. A special aptitude test should be administered testing various aspect of candidates' personality to determine their suitability. This exercise according to Obanya (2005) arouses confidence which is a necessary ingredient for acquisition and performance.

Educational guides in educational systems of different countries across the nation have different names: guide teachers, supervising teachers, counseling teachers, teacher, district educational vice principal, educational supervisor, inspector, educational inspector, head of district education department, coordinator of educational plans, head of educational department, specialized counsellor, educational planner and educational guide. However, their main task, under any titles they have and in any positions whatsoever, is to present the utmost professional assistance with teachers and to help them with more desirable development. Therefore, teaching and learning process will be enhanced and they will have more efficient function and eventually, more desirable results will be obtained. More desirable development of teachers will lead to more desirable development of students and success of 
educational supervision and guidance, which results in general satisfaction with schools accordingly. However, educational guides must be concerned about principles of supervision in order to achieve multilateral success (Soltani, 2004).

Educational supervision and guidance are among the most important duties, which are required for the management of a required educational system. Its main goal is to enhance educational status. Available educational supervision and guidance plans and quality of its endurance in appearance of educational goals play an influential role. Nowadays, educational guides as educational leaders conjoin with teachers and help them with educating in order to adjust educational status, aiming at promoting the quality of teachers' performance and removal of their problems through professional cooperation. Although educational supervision and guidance plans and titles of educational guides are different in various educational systems, their duties are similar to some extent. Uduak Imo \& Grace Bassey (2015) pointed out that job performance of teachers would be enhanced when they are properly supervised by principals using the various supervisory techniques. Osakwe (2010) assured that supervision is concerned with the provision of professional assistance and guidance to teachers and students geared towards the achievement of effective teaching and learning in the school.

Igwe (2001)stated that teachers are always worried and scared of supervision. Since supervision is unavoidable, it befits the supervisor to plan his visitation together with the teacher to avoid teachers' panic and anxiety. Many strategies have been outlined available for supervisors to help teachers advance on the job, and also to assist effective instruction in schools. The following strategies have been promoted by( Ezeocha, 1995; Obi ,2004) .

a. There should be of a good relation between teachers and supervisors.

b. The supervisor should carefully get ready for the visit and enter the class as unremarkably as possible. 
c. A conference should be held before and after the visit.

d. The supervisor should concentrate on the total learning situation, students'-teacher behavior and the attitudes of students.

e. The teacher should agrees on the visitation of the supervisor.

f. The supervisor should attempt to discover strong points in the learning situation, discuss the past during conference and give credit where it is due.

g. the supervisor should never openly show dissatisfaction of what happens in the classroom, rather, should make complimentary remarks before leaving the class.

\section{Principles of Educational Guidance and Supervision}

The basics of educational guidance and supervision have been stated by (Niknami- 2011) as follows:

- Educational supervision should be considered an inclusive part of educational plan, is considered group service.

- All teachers are in a need of educational guidance. This is an essential principle. The responsibility of this service is for school master or educational guide.

- Educational guidance and supervision plans must be prepared and designed in such a way as they meet all personal requirements of school teachers.

- All personnel, who are involved in education process, educational or non-educational staff, do need educational guidance and supervision and must follow educational plans accordingly.

- Educational guidance and supervision must explain and indicate educational goals. The educational goals and their importance must always be advised to teachers and be regarded as a base for work and activity of educational guides and teachers.

- Educational guidance and supervision must be in the direction of improvement of attitudes, knowledge, 
behavior and strengthening desirable human relations among all school teachers and act upon development of its relationship with the society.

- Educational guidance and supervision must organize extra-curricular activities of students and lead the same accordingly.

- The responsibility for improvement of educational process and plan and learning at school classes and schools is performed by an educational guide, teacher, school master and head of district education department and on the part of Ministry of Education at national level.

- Required predictions for obtaining of required facilities, associated with educational guidance and supervision plans must be included in annual budget.

- For educational guidance and supervision, both shortterm and long-term planning is mandatory.

- An educational guide, who is managerial of educational guidance and supervision plans, must benefit from counseling aids of education department, ministry of education, universities and other local, provincial and national education organizations at all levels.

Dekruyf and Pehrsson, (2011), indicated that there is a deficiency in the number of trained school counselor supervisors. At the same time, it was stated that supervisors help form intern professional identity and suggest training. Needs should concentrate on counselor development, supervision techniques, supervisory relations, and models of supervision.

\section{Concept of "Six hats strategy"}

The concept is naturally used in commercial settings; however, using the same concept in counseling can help simplify and balance different viewpoints and oppositions. (Li, 2008). Six thinking hats' strategy aids in creative thinking in which one can divide thinking; in a way that one can pay full attention to each aspect. Through using this strategy, one can divide the types of thinking and then use each type to the same subject in order to 
finish up with full color thinking on the subject. There is a suggestion that the chemical setting in the brain (neurotransmitter, etc) may be different according to the state of the human being as when one is being positive differs from when one is being negative, and from one is being creative. If this proves to be so, then there is an entire prerequisite to separate out the different components of thinking in order to do each properly. It would be impossible to have one brain setting that is ideal for all kinds of thinking. (De Bono, 1998).

The six thinking hats strategy of conducting supervision appears to provide numerous profits for counselor as a method of discovering possibilities for working with challenging customers. Counsellors often feel a great amount of stress both from the new experience of seeing clients with actual matters and from the supervision process (Bernard \& Goodyear, 2004). Because counselor may encounter stress when presented with challenging cases, supervision strategies that help minimize anxious feelings may be helpful. This model provides a beneficial structure for discovering options in working with clients, and this structure can be an essential component for managing counselor' anxiety.

This image that De Bono proposed (2008), of putting on one hat at a time, is an appropriate one in supervising counselor in group as the technique specifies a structural division of the problem-solving process. When putting on a specific color hat, the instruction is that everyone in the room must think from the standpoint of that particular hat. When used with counselor in group supervision, the supervisor calls the interns to put on one of the six hats and think collaboratively from that angle. The rule of everyone wearing the same color hat is that they jointly discover the situation from that angle completely. Everyone then removes that hat and wears another color hat in order to think inversely about the same problem, while all continue to think alike. Like the classic Gestalt empty-chair technique, The Six Thinking Hats is the equivalent of structurally moving from one 
chair then changing the focus when moving back to the other, ( Li, 2008).

\section{Rationale of "Six thinking hats' strategy"}

Somody et al . (2008) stated that insufficient supervisory support increases stress, negative feelings, and leads to counsellor role dissatisfaction. Two of the problems of counseling supervision are assisting counsellors as they form their facilitation, conceptualization, and intervention skills, plus gaining understanding of the clients they serve (Torres-Rivera et al., 2001). Counsellors are also required to identify and balance their internal differing points of view in developing a model of assimilation (Bernard \& Goodyear, 2004). The Six Thinking Hats model (De Bono, 2008) can be used in group supervision of counselor and can help in gaining awareness and making decision. The technique is a figurative way to view a problem or a counseling situation around six different viewpoints following a certain color scheme and using the theme of thinking hats .

With the six thinking hats' strategy, the thinker should have no ego and performance, in a way that the thinker can be definitely asked to give a yellow hat "performance". This is a challenge to the thinker, who will not want to look unable to perform this way. Even someone who does not like the idea does some yellow hat thinking. In the course of this yellow hat thinking, ideas may turn up just because the thinker may change his/her mind. It also can occur the other way around. A strong supporter of an idea can be asked to do a black hat performance. This may turn up difficulties that reduce the previous euphoria. . (De Bono, 1998).

The Six Thinking Hats strategy is cognitively- based utilizing De Bono's own theoretical perception of parallel Thinking (De Bono, 2008). Parallel Thinking is a method of thought processing that is practical, constructive, and helps participants to give their full attention to one point of view at a time. Similar to Bandura's (1977) Social Learning Theory, Parallel Thinking can be taught, modeled, and learned. Additionally, De Bono (2008) believes that Parallel Thinking 
supplements and supports the theory of Emotional Intelligence (Goleman, 2006) in which controlling and understanding emotions effectively and using them in thinking and reasoning correlate with life outcomes . As cited in Cigrand and Wood (2010), Wood and Rayle (2006) suggest that a supervision approach needs to be obvious, concise and practical. Such is the case in regards to six - thinking Hats based supervision.

The strategy of the Six Thinking Hats was developed to escape argumentative thinking, avoid confusion, generate focus and interaction, and achieve powerful results (De Bono, 1999). The concept is typically used in commercial settings; however, using the same concept in counseling supervision can help assist and balance miscellaneous viewpoints and polarities. The respective hats in the Six Thinking Hats strategy are described by De Bono in the following manner :

- The White Hat denotes pure knowledge gathering, data collection, and historical account. It asks about what is known. It addresses perception. The process involves discovering facts rather than personal opinions. "First class" facts consist of ones that are tested and proven, while "second class" facts contain information believed to be true. Information that is missing is also involved here. The white hat covers facts, figures, information needs, and gaps .

- The Red Hat represents feelings and emotions. This hat explores fears, likes, dislikes, loves, and hates. This hat legitimizes emotions and feeling by focusing on feelings. It addresses affect by focusing on emotions, intuition, and signal. The red hat is the contradictory of impersonal, objective information (White Hat). Here there is no need to give reasons or justification for the subjective feelings .

- The Black Hat focuses on critical negative judgments, a risk analysis. It identifies cautions, dangers and potential problems. It is the logical negative and addresses possible negative effects and what may potentially occur. It can be 
used to limit weakness in an idea. It also addresses why it does not fit - facts, experience, policy, system and ethics. It asks about what may be risky. The Black Hat Thinker is a gatekeeper, not a dream breaker .

- The Yellow Hat represents sunshine, brightness and optimism; it is positive and constructive. It addresses possibility, benefits, advantages, and savings. It asks about what could happen. The Yellow Hat addresses reframing and permits visions and dreams. Yellow Hat thinking helps keep the group going when everything looks miserable and difficult .

- The Green Hat symbolizes productiveness, growth, and the value of seeds. It involves creative thinking and the search for substitutions while generating new concepts and new perceptions. The green hat is the "thinking outside the box" creative hat. It asks for what haven't been considered before. It involves brainstorming and free association which discover new possibilities, alternatives, ideas, and concepts .

- The Blue Hat represents the management of the thinking process. The Blue Hat thinkers are like the orchestra conductors seeking the proper balance and blending of the other five hats. It leads to the conclusion. Blue Hat thinking is a final reflection on the other five hats that have been both over- and under-utilized in the problem solving exploration. The Blue hat is also responsible for summaries, overviews, and conclusions.

The six hats symbolize six types of thinking designed to systematically focus on collaborative rather than competitive thinking. The hats generate a future-oriented direction. For example, when a group of counsellors put on the Green Hat, they visualize creative solutions to the presenting problem. Since they are wearing the same color hat, their thinking is equalized. Rather than discussing that the problem has no solution, counsellors are encouraged to take brainstorming creative solutions to an apparently intractable problem. The process 
discovers only one component of parallel thinking at a time, permitting counselor the reflection time they need to be active communicators (Li, 2008).

The Six Thinking Hats system inspires performance rather than ego justification. All counsellors cooperate while wearing a specific hat even though they initially may support a contradictory point of view. The goal of this strategy is to demonstrate how many considerations each person can put forward under each respective hat. One intern's ego is no longer tangled to being correct. In applying the Six Thinking Hats with counsellors, interns, one of the main benefits is that all counsellors work together focusing conjointly on each particular hat. For example, in one group supervision session, one intern may prefer in his own problem-solving attempt to be the optimistic Yellow Hat thinker, while another intern may prefer to be the negative Black Hat thinker. Altogether as a team helps minimize such differentiated positions among counsellors. The Six Thinking Hats strategy fully utilizes the intelligence, experience, and knowledge of all counsellors in a cooperative rather than competitive manner. Thus, site supervisors will be able to assist interns and practicum students in developing their counseling skills, improving their diagnosis skills, and addresses their clients' concern (Swank and Tyson, 2012).

\section{Effect of Six thinking hats strategy}

This study is to use the six thinking hats strategy with English counselors to reflect their own creative process. Literature on six thinking hats has been more concentrated on educational areas, with a dearth of studies on the supervision field. The process of the Six Thinking Hats was developed to escape argumentative thinking, dodge confusion, create focus and interaction, and to achieve influential results (De Bono, 1999). Chen (2000) used six thinking hats to cultivate multiplicity of thinking in students in Taiwan.The red hat represents the subjective feelings and emotion of a person; the black hat represents the criticisms and judgments of a person; the white hat represents objective and neutral thinking; the 
yellow hat represents positive thinking; the green hat represents creative thinking, and the blue hat represents the integration of all the above categories of thought represented by the other five hats in order to come to a conclusion.

Wang (2003) compared fourteen elementary students who took six thinking hats training with another fourteen as a control group regarding the difference of problem-solving abilities. The study included eleven teaching units with six thinking hats, and results indicated that the experimental group had higher scores in explaining inference, casual thinking, and deciding solving methods as compared with the control groups. Tamura and Furukawa (2007) mixed De Bono's six thinking hats into internet learning to train students in problem-solving, and the study indicated that including six thinking hats decreased the teaching load of the instructors and increased the quantitative and qualitative problem solving strategies of the students as compared with students not trained using six thinking hats.

The Six Thinking Hats strategy is based on cognition using De Bono's own theoretical perception of Parallel Thinking (De Bono, 2008). Parallel Thinking provides a mode of thought processing that is practical, constructive, and invites people to give their full attention to one point of view at a time. Additionally, De Bono (2008) believes that Parallel Thinking supplements and supports the theory of Emotional Intelligence in which handling and understanding emotions effectively and using them in thinking and reasoning associate with life outcomes.

\section{Intellectual flexibility}

In order to accomplish intellectual flexibility, one should do this through feedback, assessment and personal reflection. Further, one should decide that $\mathrm{s} / \mathrm{he}$ will be more open to information even that which conflicts with her/his view (or with established views). Also, one should modify her/his mind on the basis of new information. Besides, one should value the sharing of information to encourage innovation. Moreover, one should acknowledge the importance of looking at both the big 
picture and the detail when analyzing information or assessing a situation. Also one should attempt to be innovative. (Goleman, 2006). Both Gardner (1994) and Robinson (2009) highlight that in order to understand and exploit on the natural aptitudes, talents and passions of students - they may be highly visual, or think best when they are moving,listening, or reading. Critical and creative thinking are adopted through opportunities to use tempers such as broad and adventurous thinking, reflecting on possibilities, and metacognition (Perkins 1995), and can result from intellectual flexibility, open-mindedness, adaptability and a readiness to experiment with and elucidate new questions and phenomena (Gardner 2009).

\section{Results}

To validate the first hypothesis: " There is a statistically significant difference at 0.01 between the mean scores of the study group in pre and post administrations of the situational test in favor of the post administration.", it was tested at 0.01 alpha level, the mean of scores of pretest was compared to the mean of scores of posttest (Table 4). The test is divided into five parts: "guiding the work". The mean scores of the part were calculated in the pre-administration and were 1.44 and "5.04" in post administration. The second part is entitled: organizing the work. The mean scores of this part was calculated in the pre administration, and was 1.26 while 6.16 in the post administration. The third part is "Developing staff" whose mean scores in the pre and post administration were calculated. They were 1.60 in comparison with 5.28. The fourth part is: managing performance. The mean scores of this part was calculated in the pre administration which was 0.56 while "3.60 in the post administration. The last part entitled "managing relations". The mean scores of it was 1.04 in the pre administration while 4.56 in the post administration. It is shown that the mean of scores of the post administration of the test for the experimental group (24.6) was higher than the mean of scores of the pre administration of the test (5.92) regarding the achievement test. 
Tables (4) mean scores, std. deviation \& std. error means

\begin{tabular}{|c|c|c|c|c|}
\hline Dimensions & Test & Mean scores & Std. Deviation & Std.errormeans \\
\hline \multirow{2}{*}{$\begin{array}{l}\text { Guiding the } \\
\text { work }\end{array}$} & Pre & 1.44 & 1.36 & 0.27 \\
\hline & Post & 5.04 & 1.17 & 0.23 \\
\hline \multirow{2}{*}{$\begin{array}{l}\text { Organizing the } \\
\text { work }\end{array}$} & Pre & 1.28 & 1.40 & 0.280 \\
\hline & Post & 6.16 & 1.41 & 0.281 \\
\hline \multirow{2}{*}{$\begin{array}{l}\text { Developing } \\
\text { staff }\end{array}$} & Pre & 1.60 & 1.29 & 0.26 \\
\hline & Post & 5.28 & 1.14 & 0.23 \\
\hline \multirow{2}{*}{$\begin{array}{l}\text { Managing } \\
\text { performance }\end{array}$} & Pre & 0.56 & 0.92 & 0.18 \\
\hline & Post & 3.60 & 0.82 & 0.16 \\
\hline \multirow{2}{*}{$\begin{array}{l}\text { Managing } \\
\text { relations }\end{array}$} & Pre & 1.04 & 1.43 & 0.28 \\
\hline & Post & 4.56 & 1.47 & 0.29 \\
\hline \multirow{2}{*}{ Total } & Pre & 5.92 & 3.85 & 0.72 \\
\hline & Post & 24.64 & 3.45 & 0.69 \\
\hline
\end{tabular}

In order to check if "six hats thinking strategy" is efficient in enhancing the supervisory skills of English counselors, the researcher used " $t$ " test. The results of this test are clarified in the following table (5). As shown in the table, "t" test for paired differences was used. They were 12.73 for the first part : guiding the work, "13.31" for the second part: organizing the work , " 14.73 " for the third part : developing staff, " 11.64 " for the fourth part : managing performance, and " 12.16" for the last part : managing relations. The " $t$ test" score for the whole test was 20.28. The effect size for the first parts was "0.87", "0.88" for the second, and "0.90" for the third, "0.85" for the fourth, and "0.86" for the last part. The effect size for the whole test was 0.94. All the scores are significant at 0.01 . Then the first hypothesis has been validated. Those results have been illustrated in figure (1).

Table (5) Means, std. deviation, " $t$ " scores" and effect size

\begin{tabular}{|c|c|c|c|c|c|}
\hline \multirow[b]{2}{*}{ Items } & \multicolumn{3}{|c|}{ Paired differences } & \multirow{2}{*}{$\begin{array}{c}\text { "t" } \\
\text { scores }\end{array}$} & \multirow[b]{2}{*}{$\begin{array}{c}\text { Effect } \\
\text { size }\end{array}$} \\
\hline & mean & $\begin{array}{c}\text { Std. } \\
\text { deviation }\end{array}$ & $\begin{array}{c}\text { Std.error } \\
\text { mean }\end{array}$ & & \\
\hline Guiding the work & 3.60 & 1.41 & 0.28 & 12.73 & 0.87 \\
\hline $\begin{array}{l}\text { Organizing the } \\
\text { work }\end{array}$ & 4.88 & 1.83 & 0.37 & 13.31 & 0.88 \\
\hline Developing staff & 3.68 & 1.25 & 0.25 & 14.73 & 0.90 \\
\hline $\begin{array}{l}\text { Managing } \\
\text { performance }\end{array}$ & 3.04 & 1.31 & 0.26 & 11.64 & 0.85 \\
\hline $\begin{array}{l}\text { Managing } \\
\text { relations }\end{array}$ & 3.52 & 1.45 & 0.29 & 12.16 & 0.86 \\
\hline total & 18.72 & 4.61 & 0.92 & 20.28 & 0.94 \\
\hline
\end{tabular}




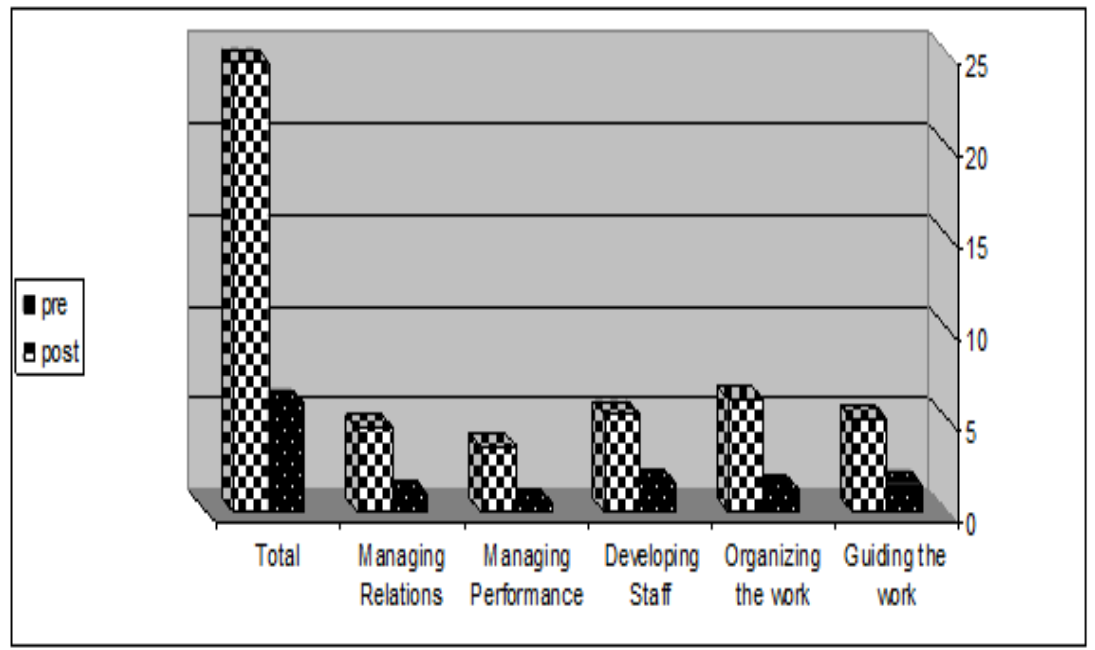

Figure (1) Illustration of Pre vs post administration of achievement test

In order to validate the second hypothesis "There is significant difference between the mean scores of the experimental group at 0.01 in pre and post administration of the intellectual flexibility' scale." Means, standard deviation and standard deviation of errors have been calculated as shown in the following table (6).It was tested at 0.01 alpha levels, the mean of scores of pre administration of the scale was compared to the mean of scores of post administration of the scale (Table 6). The scale is divided into three parts: "Considering new information and perspectives". The mean scores of the part were calculated in the pre-administration and were 5.20 and "10.36" in post administration. The second part is entitled: Integrating information. The mean scores of this part was calculated in the pre administration, and was 7.96 while 19.20 in the post administration. The third part is "Clarifying complexity" whose mean scores in the pre and post administration were calculated. They were 7.80 in comparison with 18.92. It is shown that the mean of scores of the post administration of the scale for the experimental group (48.48) was higher than the mean of scores of the pre administration of the test (20.96) regarding the scale. 
Table (6) Means, std. Deviation, std. Error Deviation of Intellectual flexibility

\begin{tabular}{|l|c|c|c|c|}
\hline \multicolumn{1}{|c|}{ Items } & & Means & $\begin{array}{c}\text { Std. } \\
\text { Deviation }\end{array}$ & $\begin{array}{c}\text { Std. Error } \\
\text { Deviation }\end{array}$ \\
\hline $\begin{array}{l}\text { Considering new } \\
\text { information and } \\
\text { perspectives }\end{array}$ & Pre & 5.20 & 1.19 & 0.24 \\
\cline { 2 - 5 } & Post & 10.36 & 1.86 & 0.17 \\
\hline $\begin{array}{l}\text { Integrating } \\
\text { information }\end{array}$ & Pre & 7.96 & 0.73 & 0.15 \\
\cline { 2 - 5 } $\begin{array}{l}\text { Clarifying } \\
\text { complexity }\end{array}$ & Post & 19.20 & 1.08 & 0.22 \\
\cline { 2 - 5 } Total & Post & $\mathbf{1 8 . 9 2}$ & $\mathbf{0 . 7 1}$ & $\mathbf{0 . 1 4}$ \\
\cline { 2 - 5 } & Pre & 20.96 & 2.15 & 0.22 \\
\cline { 2 - 5 } & Post & 48.48 & 2.49 & 0.43 \\
\hline
\end{tabular}

In order to check if "six hats thinking strategy" is efficient in enhancing the intellectual flexibility of English counselors, the researcher used " $t$ " test. The results of this scale are clarified in the following table (7). As shown in the table, "t" test for paired differences was used. They were 16.99 for the first part: considering new information and perspectives, "57.97" for the second part: integrating information, "49.21" for the third part: clarifying complexity. The "t test" score for the whole test was 52.92. The effect size for the first parts was "0.92", "0.99" for the second, and "0.99" for the third. The effect size for the whole test was 0.99 . All the scores are significant at 0.01 . Then the second hypothesis has been validated. Those results have been illustrated in figure (2).

Table (7) Paired differences results (Means-std .Deviation-std Error deviation) " $t$ ", effect size for intellectual flexibility scale

\begin{tabular}{|c|c|c|c|c|c|}
\hline \multirow[b]{2}{*}{ Items } & \multicolumn{3}{|c|}{ Paired Differences } & \multirow[b]{2}{*}{$\mathbf{t}$} & \multirow{2}{*}{$\begin{array}{c}\text { Effect } \\
\text { size }\end{array}$} \\
\hline & Means & $\begin{array}{c}\text { Std. } \\
\text { deviation }\end{array}$ & $\begin{array}{l}\text { Std.Error } \\
\text { deviation }\end{array}$ & & \\
\hline $\begin{array}{l}\text { Considering new } \\
\text { information and } \\
\text { perspectives }\end{array}$ & 5.16 & 1.52 & 0.30 & 16.99 & 0.92 \\
\hline Integrating information & 11.24 & 0.97 & 0.19 & 57.97 & 0.99 \\
\hline Clarifying complexity & 11.12 & 1.13 & 0.23 & 49.21 & 0.99 \\
\hline total & 27.52 & 2.60 & 0.52 & 52.92 & 0.99 \\
\hline
\end{tabular}




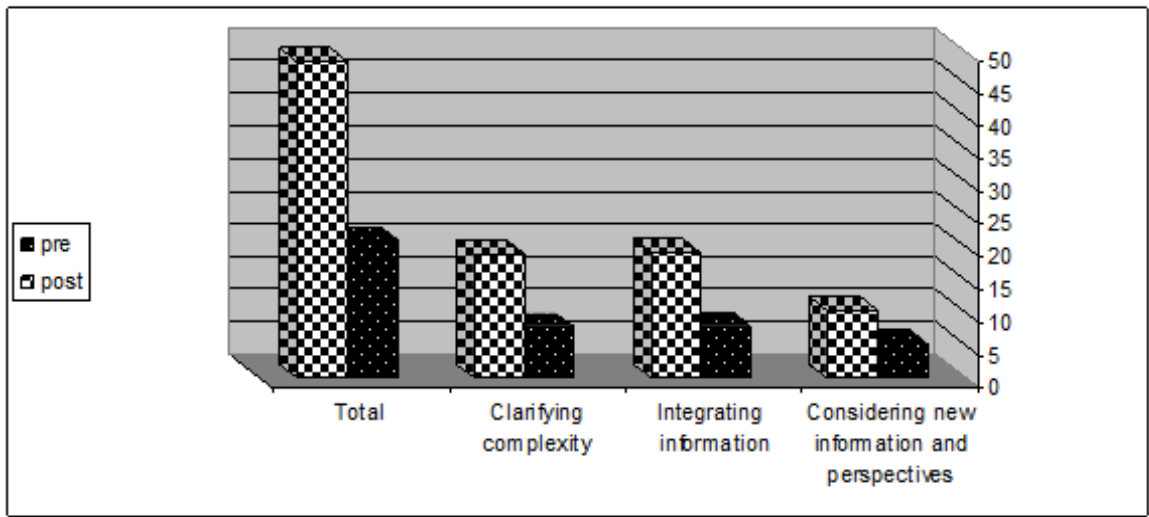

Figure (2) Pre \& post administration of "intellectual flexibility" scale

\section{Discussion}

The researcher has utilized the Six Thinking Hats problemsolving strategy in a variety of counseling and supervision activities as represented in some studies such as (Li, Lin, Nelson, \& Eckstein, 2008). In those specific supervision sessions, the supervisors were impressed by the many listening checks the technique generated including summarizing and paraphrasing each other's ideas. The supervisors collaborate on each respective hat. The brainstorming technique helps minimize separated positions among counselors. A shared nomenclature can be used both in future supervision sessions as well as by the counsellors themselves to demonstrate a systematic approach to exploring solutions and reaching consensus.

Six Hats' strategy is a creative one as was assured by ( $\mathrm{Li}, 2008)$, and was reassured in the current study. The strategy itself can be applied to any related group experience in which a creative brainstorm problem-solving method might be utilized. Two of the challenges of counseling supervision are assisting counsellors as they build their simplification, conceptualization, and involvement skills, plus gaining understanding of the patrons they serve (Torres-Rivera et al., 2001). Counselors are also 
required to identify and balance their internal differing points of view in developing a model of integration (Bernard \& Goodyear, 2004). The Six Thinking Hats strategy (De Bono, 2008) can be applied to group supervision of counselor and can aid in gaining awareness and making decision. The strategy is a metaphorical way to view a problem or a counseling situation around six different viewpoints following a certain color scheme and using the theme of thinking hats. As was clear in the current study, this strategy was effective in developing the intellectual flexibility of the supervisors because of the specific nature which split thinking into different parts and call them to think collaboratively and in a different way away from the traditional way of thinking.

\section{References}

Bernard,J.\& Goodyear,R. (2004). Fundamentals of clinical supervision. Boston, M A : Allyn and Bacon.

Cigrand, D. \& Wood, S. (2010). School counseling and solution focused site supervision : A theoretical application and case example ( Doctoral dissertation, the university of Lowa). Retrieved from http:// jsc.montana.edu/articles/vgn6.pdf.

De Bono, E. (1999). Six thinking hats. New York: Little, Brown and Company .

De Bono, E. (2008). Applications for (dB) New Think. Retrieved onMay14,2015,fromhttp://www.debonogroup.com/applic ations.htm

De Bono, E. (2008). The revolutionary nature of Parallel Thinking. Retrieved May 14, 2015, from http://www.debonogroup.com/parallel_thinking.htm

Dekruyf,L.\& Pehrsson,D. (2011). School Counseling Site Supervisor Training : An exploratory study. Counselor Education and supervision , 50(5) , 314-327.

Ezeocha, P. (1995). Modern school supervision (Supervision of instruction and issues). Owerri : International University press.

Goleman, D. (2006). Emotional Intelligence: Why it can matter more than IQ. London: Bloomsbury. 
Igwe, S. (2001). Supervision, evaluation and quality control in education . In N.A Nigeria, E.J. Ehiametalor, M.A. Ogunu and M.Nwaadiani ( Eds) current issue in educational management in Nigeria . Beni City : Nigeria Association for Educational Administration and Planning, 3(9),33-39.

Li, C., Lin, Y., Nelson, J., \& Eckstein, D. (2008). Hats off to problemsolving with couples. The Family Journal: Counseling and Therapy for Couples and Families.

Li,C. ( 2008). Six thinking hats for group supervision with counselor. Journal of humanities \& social sciences , 2(2).

McCloskey, M(2014). Learning Leadership in a changing World: Virtue and Effective Leadership in the $21^{\text {st }}$ Century, Palgrave Macmillan.

Niknami, M.(2011). Educational Guidance and Supervision, SAMT Publication.

Obi, E. (2004). Law and Education management. Enugu : Empathy International.

Obiweluozor, N; Momoh,U; Ogbonnaya , N (2013). Supervision and inspection for effective primary education in Nigeria : strategies for improvement . Academic Research International, vol. 4.

Ojelabi, A.(1981). A guide to school management. Ibadan : Valuta Educational publishers.

Orgunu, M(2005). Introduction to educational management. Benin City : Mabagun Publishers.

Osakwe, N. (2010). Relationship between principals' supervisory strategies and teachers' instructional performance in DeltaNorth Senatorial District, Nigeria. Pakistan Journal of Social Sciences, 7(6),437-440.

Soltani, I. (2004). Educational supervision : establisher of suitable grounds for improvement of educational quality, Arkan publication.

Somody , C ; Henderson , P; Cook, K \& Zambran , E. (2008). A working system of school counselor supervision . Professional school counseling , 12(1) , 22-33. 
Swank , J. \& Tyson, L. (2012). School counseling site supervisor training. A web-based approach . Professional school counseling , 16(1), 40-48.

Torres-Rivera, E., Phan, L. T., Maddux, C., Wilbur, M. P., \& Garrett, M. T. (2001). Process versus content: Integrating personal awareness and counseling skills to meet the multicultural challenge of the twenty-first century. Counselor Education \& Supervision, 41, 28-40.

Uduak Imo, E \& Grace Bassym E. (2015). Principals' Supervisory techniques and teachers' job performance in secondary schools in Ikom education Zone, Cross River State , Nigeria. British Journal of Education, 3(6), 31-41. 
